\title{
The Effect of Metadiscourse on EFL Learners' Listening Comprehension
}

\author{
Seyed Mohammad Reza Heshemi \\ Ferdowsi University of Mashhad, Iran \\ Hossein Khodabakhshzade \\ English Department, Islamic Azad University, Torbat-e-Heidarieh branch, Torbat-e-Heidarieh, Iran \\ Email: hkhodabakhshzade@gmail.com \\ Majid Elahi Shirvan \\ Ferdowsi University of Mashhad, Iran
}

\begin{abstract}
This study is an attempt to investigate the effect of metadiscourse on listening comprehension of EFL intermediate and advanced students. 120 students were assigned into four groups of 30 . There were two groups of treatment and control both in intermediate and advanced levels. Two versions of monologues with and without discourse markers were given to the control and treatment groups respectively. The result showed a significant difference between groups in advanced and intermediate levels. There was however no significant difference within the intermediate groups. So, a follow up unstructured interview was conducted to find out the possible reason. The result showed that intermediate students were not aware of the role of discourse markers in the monologues. This consciousness raising regarding discourse markers helped the premise of the study and the result of the second administration of the versions of the monologues to the intermediate groups showed a significant difference. The findings of this study clearly display the crucial role of metadiscourse and the degree of consciousness about them across different levels in listening comprehension of EFL students.
\end{abstract}

Index Terms - metadiscourse, listening comprehension, consciousness raising, discourse markers

\section{INTRODUCTION}

Fortunately, the significance of metediscourse has recently been recognized as a pivotal feature in communication. Luckily, this important issue has been touched by academia and especially language teaching milieu and its facilitative role (Crismore, 1984, 1989; Hyland, 1998, 1999; Perez \& Macia, 2002) has been acknowledged. Adding to this promising context is the shift from the traditional textual focus to more functionally oriented perspectives in the realm of metadiscourse. This new view according to Hyland (2005) considers metadiscourse as a phenomenon, which is distinct from propositional meaning and refers to the aspects of the text that embody writer-reader interactions and the relations, which are internal to the discourse.

The presence of metadiscourse has been investigated in written discourse (Hyland, 2005; Hyland, 2000, 2004; Carlson, 1998). The effect of the discourse markers has also been investigated in this field as well (Martinez, 2004; Simin and Tavangar, 2009; Cheng and Stefensen, 1996; Intraprawat, and Stefensen; 1995). Contrary to all these attempts in determining the role of discourse markers in written discourse, the crucial role of metadiscourse in spoken discourse seems to have been ignored.

Students of English as a foreign language are more required to listen to and comprehend great amounts of second language input (Eslami and Eslami, 2007). The importance of metadiscourse in listening comprehension has attracted the attention of some scholars (Chaudron and Richards, 1986; Flowerdew and Tauroza, 1995; Perez and Macia, 2002).

Despite these attempts to underscore the role of metadiscourse in written discourse, there has been little attention paid to the role of metadiscourse in listening comprehension. So this study is partially inspired by the few studies conducted recently and is hopeful to highlight the crucial role of discourse markers in EFL students listening comprehension.

\section{A. Metadiscourse}

Metadiscourse is a widely used term in current discourse analysis and language education that involves speakers or writers not only in producing but an interaction between text producers, text and their audience (Hyland, 2005). In fact text producers try to anticipate their audience expectations, requirments and resources to affect their understanding to pave the way of an effective communication. Until recently there has been an overarching ideology quite limited to conveying the ideas by focusing on the grammatical patterns and rules. Today, however, new conceptualizations of metadiscourse have led to a shift towards the means that speakers or writers try to express their attitudes. Hyland (2005) 
argues that " metadiscourse embodies the idea that communication is more than just the exchange of information, goals or services, but also involves he personalities, attitudes and assumptions of those who are communicating" (p. 3).

Halliday's (1994) functional, pragmatic approach to language is of great help in conceptualizing, understanding and classifying metadiscourse. He considers three major functional systems for the language i.e. ideational, interpersonal, and textual. The ideational level concerns with the propositions, the interpersonal layer is dealt with all those personal feelings, personality expressions as well as the social interplay along with different interactional forms. The textual layer is quite essential for understanding the ideational and interpersonal meaning. Following this functional view, metadiscourse can be classified into two broad categories i.e. the interpersonal and textual in which we can find other subcategories as well. Vande Kopple (1985) believes that textual metadiscourse reveals a discoursal relationship between individual propositions that culminate in a cohesive and coherent text. This is what Lyons (1997) refers to as text reflexivity, or "the capacity of natural language to refer to or describe itself" (p. 5)

Different scholars have investigated the role of metadiscourse instruction in different skills of the language (Dastjerdi and shirzad, 2010; Jalalifar and Alipour, 2007; Martinez, 2004). The common result of these studies displays the positive effect of discourse markers instruction.

Dastjerdi and Shirzad (2010) investigated the effect of explicit teaching of metadiscourse markers on EFL learners' writing ability at three levels of advanced, intermediate, and elementary. They found that explicit instruction of metadiscourse makers significantly increased EFL learners' writing ability at three levels. Their findings also revealed that intermediate EFL learners took more benefits of familiarity with discourse markers than those at the other levels in their writing ability.. In other words, intermediate EFL learners improved their writing more significantly than the other groups.

\section{B. Metadiscourse and Academic Lectures as Monologues}

The lecture discourse has been analyzed by some scholars (Murphy and Candlin, 1979; Chaudron, 1988; Shing Chiang and Dunkel, 1992; Allison and Tauroza, 1995). They have in fact considered factors such as speech rate, cultural differences, note-taking practices, listening strategies and discourse organization. Listening to the lectures as monologues has always been one of the demanding jobs for foreign language learners. It has also been an important skill for university students (Flowerdew and Miller, 1992). Different scholars have considered lectures as monologues from different perspectives. Some have focused on the macro structure of lectures (Olsen and Huckin, 1990), others have paid attention to the interactional practices of lecture comprehension (Morell, 2004).

\section{METHOD}

\section{A. Participants}

The participants in this study included four groups of 30, two intermediate and two advanced, students taking IELTS training courses at Kishair English Institute, Mashhad. Iran. All the participants' first language was Farsi and their age ranged from 22 to 43 with the mean of 33 .

First a test of TOEFL derived from Actual TOEFL tests was given to 112 EFL students studying at Kish Air English institute. Then those whose scores ranged between 450 and 550 were considered as intermediate. Also, those whose scores ranged above 550 were considered as advanced learners. Therefore, 65 of the test takers were labeled intermediate and 62 advanced. Other participants, whose scores were lower than 450 and did not serve a purpose for the study were excluded from them. For the sake of the purpose of the study, both groups of scores were ranked from the highest to the lowest. Then in each group the one with highest score was assigned to one group and the second highest score was assigned to another group and this process continued to the one with the lowest score. So the participants were randomly assigned into four groups. Moreover, to make the number of each group equal, the researchers included 30 students in each group. Finally, in order to make sure that the difference between the mean scores is not significant and the two intermediate and the two advanced groups are the same with regard to the construct tested, the researchers used an independent t-test.

TABLE 1.

INDEPENDENT SAMPLES T-TEST FOR THE INTERMEDIATE GROUPS

\begin{tabular}{|c|c|c|c|c|c|c|c|c|c|c|}
\hline & & \multicolumn{2}{|r|}{$\begin{array}{c}\text { Test for } \\
\text { of Variances }\end{array}$} & \multicolumn{7}{|c|}{ t-test for Equality of Means } \\
\hline & & \multirow[b]{2}{*}{$\mathrm{F}$} & \multirow[b]{2}{*}{ Sig. } & \multirow[b]{2}{*}{$\mathrm{T}$} & \multirow[b]{2}{*}{ Df } & \multirow{2}{*}{$\begin{array}{l}\text { Sig. (2- } \\
\text { tailed) }\end{array}$} & \multirow{2}{*}{$\begin{array}{l}\text { Mean } \\
\text { Difference }\end{array}$} & \multirow{2}{*}{$\begin{array}{l}\text { Std. Error } \\
\text { Difference }\end{array}$} & \multicolumn{2}{|c|}{$\begin{array}{l}95 \% \text { Confidence Interval of the } \\
\text { Difference }\end{array}$} \\
\hline & & & & & & & & & Lower & Upper \\
\hline GE & $\begin{array}{l}\text { Equal variances } \\
\text { assumed }\end{array}$ & .166 & .46 & 9.064 & 58 & .63 & 2.20 & & 2.1148 & 3.2936 \\
\hline & $\begin{array}{l}\text { Equal variances not } \\
\text { assumed }\end{array}$ & & & 9.109 & 57.9 & .63 & 2.20 & .29689 & 2.1177 & 3.2907 \\
\hline
\end{tabular}


TABLE 2.

INDEPENDENT SAMPLES T-TEST FOR THE ADVANCED GROUPS

\begin{tabular}{|c|c|c|c|c|c|c|c|c|c|c|}
\hline & \multicolumn{2}{|c|}{$\begin{array}{lr}\text { Levene's } & \text { Test } \\
\text { Equality } & \text { of } \\
\text { Variances } & \end{array}$} & \multicolumn{7}{|c|}{ t-test for Equality of Means } \\
\hline & & \multirow[b]{2}{*}{$\mathrm{F}$} & \multirow[b]{2}{*}{ Sig. } & \multirow[b]{2}{*}{$\mathrm{T}$} & \multirow[b]{2}{*}{ Df } & \multirow{2}{*}{$\begin{array}{l}\text { Sig. (2- } \\
\text { tailed) }\end{array}$} & \multirow{2}{*}{$\begin{array}{l}\text { Mean } \\
\text { Difference }\end{array}$} & \multirow{2}{*}{$\left|\begin{array}{l}\text { Std. Error } \\
\text { Difference }\end{array}\right|$} & \multicolumn{2}{|c|}{$95 \%$ Confidence Interval of the Difference } \\
\hline & & & & & & & & & Lower & Upper \\
\hline GE & Equal variances assumed & .166 & .46 & 9.064 & 58 & .67 & 2.70 & .29837 & 2.1148 & 3.2936 \\
\hline & $\begin{array}{l}\text { Equal variances not } \\
\text { assumed }\end{array}$ & & & 9.109 & 57.9 & .61 & 2.70 & .29689 & 2.1177 & 3.2907 \\
\hline
\end{tabular}

The results of this test revealed that the two groups at both levels, intermediate and advanced did not significantly differ from each other in terms of their performance on the T-test. It means that the participants of the two groups were equal with regards to their GE (General English) ability.

\section{B. Materials}

The materials used for this study consisted of 5 monologues based on section 4 of IELTS examinations. 5 of these monologues were derived directly from IELTS tests. Since such section consists of monologues with are rich in metadiscourse (Hyland, 2005), they serve the purpose of the study very well. The other 5 monologues were based on the first group of monologues but the metadiscourse were excluded.

\section{Procedure}

First, the researchers in the study selected five monologues from the original IELTS exams. Then in order to organize the second group of monologues, they excluded the metadiscourses from the original ones. Hyland's model of interpersonal metadiscourse (2005) was determined for underlining the metadiscourse and their exclusion from the original monologues. Then both groups of monologues were recorded by British native-like voices. Next, the recorded monologues were given to some university teachers and four university students of TEFL to check the content of the records. Then, the recorded monologues were given to the groups. The learners in the experimental groups listened to the original monologues and those in the control groups listened to those with the metadiscourse excluded.

\section{RESULTS}

The first research question was "Is there any difference in intermediate EFL learners' listening comprehension with regard to the inclusion and exclusion of metadiscourses?" The following table shows the mean scores of the intimidate control and experimental groups.

TABLE 3

ILLUSTRATES WHETHER SUCH DIFFERENCE IN MEAN SCORES OF THE TWO GROUPS IS SIGNIFICANT OR NOT.

\begin{tabular}{|ll|l|l|l|l|}
\hline & Group & $\mathrm{N}$ & Mean & Std. Deviation & Std. Error Mean \\
\hline Intermediate & Experimental & 30 & 17.2043 & 1.94330 & .21460 \\
& Control & 30 & 13.5000 & 1.76486 & .20516 \\
\hline
\end{tabular}

\begin{tabular}{|c|c|c|c|c|c|c|c|c|c|c|}
\hline & & \multicolumn{2}{|c|}{$\begin{array}{l}\text { Levene's Test for } \\
\text { Equality of } \\
\text { Variances }\end{array}$} & \multicolumn{7}{|c|}{ t-test for Equality of Means } \\
\hline & & \multirow[b]{2}{*}{$\mathrm{F}$} & \multirow[b]{2}{*}{ Sig. } & \multirow[b]{2}{*}{$\mathrm{T}$} & \multirow[b]{2}{*}{ Df } & \multirow{2}{*}{$\begin{array}{l}\text { Sig. }(2- \\
\text { tailed) }\end{array}$} & \multirow{2}{*}{$\begin{array}{l}\text { Mean } \\
\text { Difference }\end{array}$} & \multirow{2}{*}{$\begin{array}{l}\text { Std. Error } \\
\text { Difference }\end{array}$} & \multicolumn{2}{|c|}{$\begin{array}{l}95 \% \text { Confidence Interval of } \\
\text { the Difference }\end{array}$} \\
\hline & & & & & & & & & Lower & Upper \\
\hline & $\begin{array}{l}\text { Equal variances } \\
\text { assumed }\end{array}$ & .166 & .46 & 9.064 & 58 & .34 & 2.70 & .29837 & 2.1148 & 3.2936 \\
\hline & $\begin{array}{l}\text { Equal variances not } \\
\text { assumed }\end{array}$ & & & 9.109 & 57.9 & .31 & 2.70 & .29689 & 2.1177 & 3.2907 \\
\hline
\end{tabular}

As table 4 shows the difference between the two groups is not significant. It means that the inclusion and exclusion of metadiscourses has no significant effect on intimidate EFL learners' listening comprehension.

The second research question was "Is there any difference in advanced EFL learners' listening comprehension with regard to inclusion and exclusion of Metadiscourses?" The following table demonstrates the mean scores of the advanced experimental and control groups. 


\begin{tabular}{|ll|l|l|l|l|}
\hline & Group & N & Mean & Std. Deviation & Std. Error Mean \\
\hline Advanced & Experimental & 30 & 17.4021 & 1.94330 & .21460 \\
& Control & 30 & 14.5000 & 1.76486 & .20516 \\
\hline
\end{tabular}

In order to see whether the difference in mean scores of the two groups is significant or not, the researchers used an independent t-test (Table 5)

\begin{tabular}{|c|c|c|c|c|c|c|c|c|c|c|}
\hline & & \multicolumn{2}{|c|}{$\begin{array}{l}\text { Levene's Test for } \\
\text { Equality of } \\
\text { Variances }\end{array}$} & \multicolumn{7}{|c|}{ t-test for Equality of Means } \\
\hline & & \multirow[b]{2}{*}{$\mathrm{F}$} & \multirow[b]{2}{*}{ Sig. } & \multirow[b]{2}{*}{$\mathrm{T}$} & \multirow[b]{2}{*}{ Df } & \multirow{2}{*}{$\begin{array}{l}\text { Sig. }(2- \\
\text { tailed) }\end{array}$} & \multirow{2}{*}{$\begin{array}{l}\text { Mean } \\
\text { Difference }\end{array}$} & \multirow{2}{*}{$\begin{array}{l}\text { Std. Error } \\
\text { Difference }\end{array}$} & \multicolumn{2}{|c|}{$\begin{array}{l}\text { 95\% Confidence Interval of the } \\
\text { Difference }\end{array}$} \\
\hline & & & & & & & & & Lower & Upper \\
\hline GE & $\begin{array}{l}\text { Equal variances } \\
\text { assumed } \\
\text { Equal variances not } \\
\text { assumed }\end{array}$ & .166 & .46 & $\begin{array}{l}9.064 \\
9.109\end{array}$ & 57.9 & $\begin{array}{l}.000 \\
.000\end{array}$ & 2.70 & $\begin{array}{l}.29837 \\
.29689\end{array}$ & $\begin{array}{l}2.1148 \\
2.1177\end{array}$ & $\begin{array}{l}3.2936 \\
3.2907\end{array}$ \\
\hline
\end{tabular}

As table 5 shows, there is a significant difference between the mean scores of the two groups. It means that metadiscourses have a significant effect on advanced learners' listening comprehension.

\section{DISCUSSION}

The results of the first research question showed that the exclusion of metadiscourses has no significant effect on intermediate EFL learners' listening comprehension. Since that was not the case for the advanced ones, the researchers decided to conduct an unstructured interview with 5 learners of each group to gain further insights into the causes of such results. Therefore, 5 learners of each group were invited for a half hour interview with the researchers. In order to elicit reliable answers from the interviewees and to keep them motivated for the interview, the researchers paid each one 20, 000 Rials, around 20\$. The unstructured interview was used in this study because as Dörnyei (2007) words it

allows maximum flexibility to follow the interview in unpredictable directions, with only minimal interference from the research agenda. The intention is to create a relaxed atmosphere in which the respondent may reveal more than he/she would in informal contexts, with the interviewer assuming a listening role...... This kind of interview is most appropriate when a study focuses on the deep meaning of particular phenomena (p.136).

Having conducted the interviews, the researchers found that almost all the intermediate interviewees, 9 out of 10, 5 in the control group and 4 in the experimental group, were not aware of the concept of metadiscourse. However, most of the advanced learners interviewed, 9 out of 10, 4 in the control group and 5 in the experimental one, were familiar with the concept of metadiscourse. Thus, based on the findings of the interviews, the researched decided to expand the study. They conducted a further study on the same intermediate control and experimental groups. But this time, both experimental and control groups were consciously familiarized with the concept of metadiscourse by the researchers. Then, both the control and experimental groups were given five monologues different from the previous ones. However, the control group received the ones with the metadiscourses excluded. Next, the mean scores of both groups were observed. The following table demonstrates the mean scores of both groups.

\begin{tabular}{|ll|l|l|l|l|}
\hline & Group & $\mathrm{N}$ & Mean & Std. Deviation & Std. Error Mean \\
\hline Intermediate & Experimental & 30 & 16.2043 & 1.94330 & .21460 \\
& Control & 30 & 14.0521 & 1.76486 & .20516 \\
\hline
\end{tabular}

An independent t-test was used to see whether such difference in mean scores is significant or not (table 6)

\begin{tabular}{|c|c|c|c|c|c|c|c|c|c|c|}
\hline & & \multicolumn{2}{|c|}{$\begin{array}{l}\text { Levene's Test for } \\
\text { Equality of } \\
\text { Variances }\end{array}$} & \multicolumn{7}{|c|}{ t-test for Equality of Means } \\
\hline & & \multirow[b]{2}{*}{$\mathrm{F}$} & \multirow[b]{2}{*}{ Sig. } & \multirow[b]{2}{*}{$\mathrm{T}$} & \multirow[b]{2}{*}{ Df } & \multirow{2}{*}{$\begin{array}{l}\text { Sig. (2- } \\
\text { tailed) }\end{array}$} & \multirow{2}{*}{\begin{tabular}{|l|} 
Mean \\
Difference
\end{tabular}} & \multirow{2}{*}{$\begin{array}{l}\text { Std. Error } \\
\text { Difference }\end{array}$} & \multicolumn{2}{|c|}{$\begin{array}{l}\text { 95\% Confidence Interval of the } \\
\text { Difference }\end{array}$} \\
\hline & & & & & & & & & Lower & Upper \\
\hline GE & $\begin{array}{l}\text { Equal variances } \\
\text { assumed } \\
\text { Equal variances not } \\
\text { assumed }\end{array}$ & .166 & .46 & 9.064 & 58 & .63 & $\begin{array}{l}.000 \\
.000\end{array}$ & $\begin{array}{l}.29837 \\
.29689\end{array}$ & $\begin{array}{l}2.1148 \\
2.1177\end{array}$ & $\begin{array}{l}3.2936 \\
3.2907\end{array}$ \\
\hline
\end{tabular}


As table 7 shows, the difference in mean scores is significant at $\mathrm{P}<0.001$. It means that exclusion of metadiscourse can significantly influence intermediate EFL learners' listening comprehension if they are already familiar with the concept of metadiscourse.

The findings of this study also corroborate those of Dastjerdi and Shirzad (2010). As mentioned in the review of literature Datjerdi and Shirzad (2010) found that explicit teaching of discourse markers can improve EFL learners' Writing ability. In this study the researchers found that metadiscourse play an important role in EFL learners' listening comprehension. Both studies highlight the significant role of meta-discourse on the EFL skills such as writing and listening comprehension.

Moreover, Dastjerdi and Shirzad (2010) indicated that intermediate EFL learners could improve their writing ability more significantly than those at the elementary and advanced levels when they learned the metadiscourse markers explicitly. In this study, the researchers found that if intermediate EFL learners become consciously aware of the role of meta-discourse makers in their listening comprehension, their performance can improve their listening ability more significantly than when they are not aware of them. Therefore, both studies emphasize the explicit teaching or awareness of metadiscourse-markers can help intermiduate EFL learners to improve not only their writing ability but also their listening comprehension ability.

\section{Conclusion}

The results of the present study indicate that the effect of meta-discourse on EFL listening comprehension should not be neglected by the teachers. Also, metadicourse can play a more influencing role on listening if the consciousness of the EFL learners' is raised by their teachers, especially at the intermediate level.

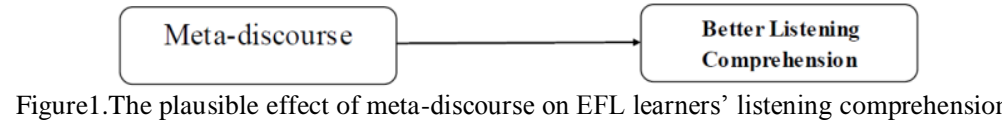

Researchers interested in the field of meta-discourse can do more research on the role meta-discourse markers on the other skills and subskills of English Language such as reading comprehension and speaking ability.

\section{REFERENCES}

[1] Alison, D. \& Tauroza, S. (1995). The effect of discourse organization on lecture comprehension. English for Specific Purposes, 14(2), 157-173.

[2] Carlson, S.B. (1988). Cultural differences in writing and reasoning skills. In A.C. Purves (Ed.), Writing Across Languages and Cultures: Issues in contrastive rhetoric (pp. 227-260). Newbury Park, CA: Sage.

[3] Chaudron, C. \& Richards, J. C. (1986). The effect of discourse markers on the comprehension of lectures. Applied Linguistics, 7, 113-127.

[4] Chaudron, C. (1988). Second language classrooms. Cambridge: Cambridge University Press.

[5] Cheng, X and Stefensen, M. (1996). Metadiscourse: A techniquein improving students writing. Research in the Teaching of English, 30, 149-181.

[6] Crismore, A. (1984). The rhetoric of social studies textbooks: Metadiscourse. Journal of Curriculum Studies, 16(3), 279-296.

[7] Crismore, A. (1989). Talking with readers: Metadiscourse as rhetorical act. New York: Peter Lang.

[8] Eslami, R. Z. \& Eslami, R. A. (2007). Discourse markers in academic lectures. Asian EFL Journal. 9(1), 22-38.

[9] Flowerdew, J., \& Tauroza, S. (1995). The effect of discourse markers o second language lecture comprehension. Studies in Second Language Acquisition, 17, 435-458.

[10] Halliday, M. A. K. (1994). An introduction to functional grammar (2 ${ }^{\text {nd }}$ ed.).London: Edward Arnold.

[11] Hyland, K. (1998). Persuasion and context: The pragmatics of academic metadiscourse. Journal of Pragmatics, 30 (4), 437-455.

[12] Hyland, K. (1999). Talking to students: Metadiscourse in introductory course books. English for Specific Purposes, $18(1)$, 3-26.

[13] Hyland, K. (2004). Disciplinary interactions: Metadiscourse in L2 postgraduate writing. Journal of Second Language Writing, 13, 133-151.

[14] Hyland, K. (2005). Exploring interaction in writing. London: Continuum.

[15] Intraprawat, P. \& Stefensen, M. S. (1995). The use of metadiscourse in good and poor ESL essays. Journal of Second Language Writing, 4(3), 253-272.

[16] Jalilifar, A. \& Alipour, M. (2007). How explicit instruction makes a difference: Metadiscourse markers and EFL learners' reading comprehension skill. Journal of College Reading and Learning, 38(1), 127-148.

[17] Martinez, A. C. L. (2004). Discourse markers in the expository writing of Spanish university students. IBERICA, 8, 63-80.

[18] Morell, T. (2004). Interactive lecture discourse for university EFL students. English for specific purposes, 23, 325-338.

[19] Murphy, D.F. \& Candlin, C.N. (1979). The engineering lecture discourse and listening comprehension. Practical papers in English Language Education, 2, 1-79.

[20] Olsen, L. A., \& Hukin, T. N. (1990). Point-driven understanding in engineering lecture comprehension. English for Specific Purposes, 9, 33-47.

[21] Perez, M. A. \& Macia, I. A. (2002). Metadiscourse in lecture comprehension: Does it really help foreign language learners? Allantis, 14(2), 3-21.

[22] Perez, M.A. \& Macia, I. A. (2002). Metadiscourse in lecture comprehension: Does it really help foreign language learners? Allantis, 14(2), 3-21. 
[23] Shing Chiang, C. \& Dunkel, P. (1992). The effect of speech modification, prior knowledge, and listening proficiency on EFL lecture learning. TESOL Quarterly, 26(2), 345-374.

[24] Simin, S. \& Tavangar, M. (2009). Metadiscourse knowledge and use in Iranian EFL writing. Asian EFL Journal, 11, $230-255$.

[25] Vahid Dastjerdi, H., \& Shirzad, M. (2010). The impact of explicit instruction of metadiscourse markers on EFL learners' writing performance. The Journal of Teaching Language Skills, 2(2), 154-174.

[26] Vande Kopple, W. (1985). Some exploratory discourse on metadiscourse. College composition and communication, 36, 82-93.

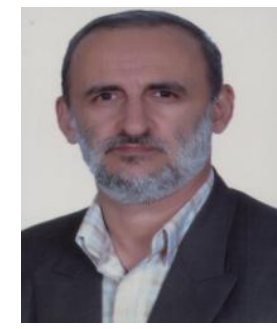

Seyed Mohammad Reza Hashemi is an associate Teacher at Ferdowsi University of Mashhad, Iran. He has published several articles in TEFL. His main interests are Stylistics and Critical Discourse Analysis.

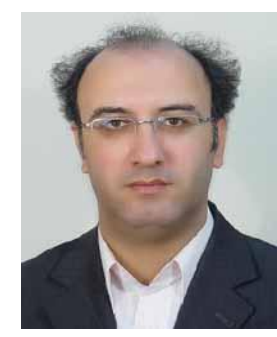

Hossein Khodabakhshzade is a faculty member at Izlamic Azad Univerity of Torbat-e- Heidaieh. He is currently a PhD candidate in TEFL at Ferdowsi University of Mashad, Iran.

He has published several articles and has presented articles in national and international conferences. His areas of interests are mostly Language assessment, Methodology in language teaching and teacher training.

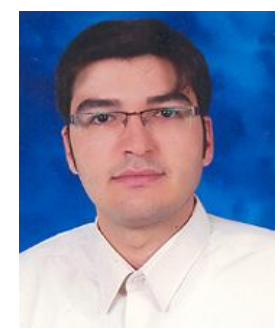

Majid Elahi Shirvan is a Ph.D. candidate in TEFL at Ferdowsi university of Mashhad, Iran. He is the coauthor of Learn 301 Advanced Words in an Easy Way. He has published several articles and has participated in different national and international conferences. 